\title{
Rates and risk factors associated with the progression of HIV to AIDS among HIV patients from Zhejiang, China between 2008 and 2012
}

Lin Chen ${ }^{1 *}$, Jiezhe Yang ${ }^{1}$, Renjie Zhang ${ }^{1}$, Yun Xu' ${ }^{1}$, Jinlei Zheng ${ }^{1}$, Jianmin Jiang ${ }^{1}$, Jun Jiang ${ }^{1}$, Lin He ${ }^{1}$, Ning Wang ${ }^{2}$, Philip Chun Yeung ${ }^{3}$ and Xiaohong Pan ${ }^{4}$

\begin{abstract}
Objectives: The objective of this study was to determine the rate of acquired immune deficiency syndrome (AIDS) in Zhejiang province and to identify specific factors associated with progression of this disease.

Methods: This study utilized a retrospective cohort to identify the specific factors involved in the progression of human immunodeficiency virus (HIV) to AIDS. We collected data of patients existing in care between 2008 and 2012 from the national surveillance system databases. We performed our analyses using a multivariate Cox proportional hazards model.

Results: This study included 9216 HIV-positive patients (75.6 \% male), which yielded 12,452 person-years (py) of follow-up-data. The AIDS progression rates were $33.9 \%$ (2008), $33.6 \%$ (2009), $38.1 \%$ (2010), $30.6 \%$ (2011) and $25.9 \%$ (2012). We observed a significant reduction in the rate of progression Of HIV to AIDS post-2010 (Pearson $\chi^{2}=4341.9$, $P<0.001)$. The cumulative AIDS progression incidence rates were 33.4, 35.4, 36.4, 37.0 and 37.04 per 100 py in 1 each of the 5 years of follow-up. This study found that age was an independent risk factor for the progression of HIV to AIDS. Compared with patients infected with HIV by homosexual transmission, patients infected with HIV by heterosexuals transmission or blood transfusion had a reduced hazard ratio $(H R)$ for progression to AIDS (heterosexual transmission: $H R=0.695,0.524, P=0.007$; blood transfusion: $H R=0.524, P=0.015$ ). Diagnosed with HIV from 2011 to 2012 and having a higher CD4+ cell count (350-500 cells $/ \mathrm{mm}^{3}$; or $>500$ cells $/ \mathrm{mm}^{3}$ ) at baseline were independently associated with lower rates of HIV progression to AIDS [HR $=0.382,0.380,0.187, P<0.001]$. Patients with a CD+T-cell count of 200-350 cells $/ \mathrm{mm}^{3}$ or greater than 350 cells $/ \mathrm{mm}^{3}$ were less likely to develop AIDS following HIV diagnosis than were those patients without HAART treatment.

Conclusion: This study found a high progression rate from HIV to AIDS in HIV patients residing within Zhejiang province from 2008 to 2010. This rate decreased after 2010, which coincided with the new criteria for HAART treatment, which likely contributed to the observed reduction in the rate of progression. Initiation of HAART with higher CD4+ T-cell count may reduce rate of AIDS progression. Based on our results, we conclude that efficient strategies for HIV screening, as well as early diagnosis and treatment are necessary to reduce the progression of HIV to AIDS.
\end{abstract}

Keywords: HIV, AIDS, HAART

\section{Background}

Human immunodeficiency virus (HIV), the causative agent of acquired immune deficiency syndrome (AIDS),

\footnotetext{
${ }^{*}$ Correspondence: Ichen@cdc.zj.cn

${ }^{1}$ Zhejiang Provincial Center for Diseases Control and Prevention, Hangzhou, China

Full list of author information is available at the end of the article
}

has posed a major global threat since its discovery in 1983 [1]. Today, approximately 40 million people globally are infected with HIV. Specifically, in China, there is a steadily increasing rate in the prevalence of HIV and subsequent progression to AIDS [2, 3]. In 2009, AIDS became the leading cause of death due to infectious agents in China [4]. Prior to 2009, the People's Republic of China 
(PRC) launched the Four Frees and One Care' (FFOC) policy in 2003 to reduce the transmission of HIV. 'Four Frees' represent free antiretroviral treatment, prevention of mother-to-child transmission, voluntary counselling and testing, schooling for Children orphaned by AIDS' [5]. 'One care' represents care and economic assistance to the households of people living with HIV/AIDS. In 2010, the criteria for highly active antiretroviral therapy (HAART) was broadened from standards that included patients with a CD4+ T-cell count $\leq 200$ cells $/ \mathrm{mm}^{3}$ to those that included patients with a CD4+ T-cell count $\leq 350$ cells $/ \mathrm{mm}^{3}$. This modification allowed a greater number of people living with HIV (PLHIV) receive free treatment at an earlier stage of the infection. Zhejiang province, located on the southern coast of China, is one of the most developed areas in China. In 2012, there were a total of 8144 HIV/AIDS patients in Zhejiang. Interestingly, Zhejiang has a higher rate of HIV/AIDS patients than other Chinese provinces with similar populations and economic levels [6, 7]. Although $57.0 \%$ of the total patients in Zhejiang have been treated with HAART.

The number of newly diagnosed HIV cases has steadily increased between 2008 and 2012 (from 1066 to 2744 patients). Despite HAART treatment, the number of HIV/AIDs patients in Zhejiang has increased. Therefore, it is essential that we understand the efficacy of current HIV/AIDS management strategies so that we can develop supplementary measures that will delay or prevent the progression of AIDS and, ultimately, reduce the rate of mortality.

Previous studies involving mathematical prediction models suggest that HIV-infected patients to in developing countries are more likely to acquire AIDS and subsequently die compared with those in developed countries [8-10]. In this study, we retrospectively analyzed data from HIV-infected patients in Zhejiang collected from 2008 to 2012. The goal of this study was to utilize patient data to identify risk factors associated with AIDS progression. Because China is the largest developing country in the world, this study examined whether the risk factors identified in developed countries might also be responsible for AIDS progression in developing countries.

\section{Methods}

\section{Data source}

A retrospective cohort study was conducted to evaluate the progression of HIV to AIDS in HIV-infected patients from Zhejiang, China. We utilized patient data from the Chinese National Case Reporting System collected from January 1, 2008 to December 31, 2012. After patients had been positively confirmed as HIV-positive, a uniform questionnaire designed by the Chinese Centers for Disease Control was used to collect patient information.
The data were then uploaded to the National Surveillance System Database and the National Treatment Database. Patient information is confidential and could not be released without permission. Information retrieved from these databases included the following: demographic characteristics, disease progression (HIV or AIDS), year of confirmed diagnosis, method of diagnosis, transmission mode, dates, as well as details regarding AIDS progression and treatment [e.g., date of AIDS onset, HAART treatment dates, death (if applicable) CD4+ T-cell count]. After diagnosis, patients were followed until they died, were lost from the database, or until December 31, 2012. Observation stops once AIDS were developed.

\section{Sampling method}

Between January 1, 2008 and December 31, 2012, a total of 9216 HIV-positive patients were enrolled in Group One. All participants had to meet the following criteria: diagnosed as HIV-positive before 2008 and alive on December 31, 2007 or newly diagnosed with HIV during 2008 to 2012; HIV-positive status was defined as testing positive for an HIV-1 on ELISA and Western blot analysis. During the 5 years study observation, 441 (4.8 \%) subjects died or dropped out of the database.

Our analysis also focused on the role of potential risk factors in HIV progression to AIDS. Therefore, Group Two consisted of patients with the following characteristics: newly diagnosed as HIV-positive from 2008 to 2012, had CD4+ T-cell count tested within 3 months after diagnosis, no immediate progression to AIDS. Of the 9216 patients, 4121 had AIDS at the time of HIV-positive diagnosis to AIDS. Patients who developed AIDS within 6 months after HIV diagnosis, or patients without a CD4 test within 3 month after diagnosis were excluded in the study to reduce bias. Thus, 3898 patients were enrolled in group two.

\section{Diagnosis of AIDS}

In 2006, the World Health Organization (WHO) stated the progression of HIV to AIDS has occurred when an individual has a CD4+ T-cell count less than or equal to 200 cells $/ \mathrm{mm}^{3}$, or WHO stage 3 or 4 [11].

\section{Statistical analysis}

The survival time of those patients diagnosed with AIDS was estimated by the number of years from their first visit to the midpoint between the last visit with AIDS-free and the first visit with AIDS. Individuals who remained AIDS-free were monitored until their last follow-up visit. All statistical analyses for this report were conducted using SPSS 17.0 statistical analysis software package (SPSS, Chicago, IL, USA). Data from Group One were analyzed using an abridged life table method, which 
described the incidence of AIDS from 2008 to 2012; and estimate the effect of HAART treatment on patient outcomes. For Group Two, Cox proportional hazards models were fitted to examine the effects of region, gender, age, education, marriage, occupation, CD4+ T-cell count and HAART treatment on the time to between HIV diagnosis and AIDS diagnosis. Results with $\mathrm{p}$ values of less than 0.05 were considered statistically significant. We excluded patients with missing data from the analysis.

\section{Results}

\section{Patient characteristics}

The mean age of the 9216 HIV-positive patients enrolled in Group One was 35 years (range $=1-88$ years). In this study, the majority of patients were men $(75.6 \%)$ and $45.3 \%$ were married. In terms of educational level, approximately $69.0 \%$ patients did not proceed beyond junior high school. Additionally, $47.4 \%$ patients were migrants from other provinces and most patients held one of the following jobs:worker, famer and commercial servant (64.3\%). Patients demographic characteristics are presented in Table 1.

\section{AIDS development from 2008 to 2012}

A total of 9216 patients in Group One were followed up for 12,452 person-years (py). By December 31, 2012, 3868 patients progressed from HIV to AIDS in Group one. There were 441 patients who returned to their home country or died (ranging from 0.30 to 4.70 person-years following HIV diagnosis). Following HIV diagnosis, the mean CD4+ T-cell count was 437 cells $/ \mathrm{mm}^{3}$. No significant differences between the demographic characteristics of patients who stopped being monitored during the time of our study compared with those patients whose information was available throughout the study time frame (data not shown) (Table 2).

During the entire observation period (2008-2012), HIV-positive patients progressed to AIDS (Group one) at the following rates: $33.9 \%$ (2008), $33.6 \%$ (2009), $38.1 \%$ (2010), $30.6 \%$ (2011) and $25.9 \%$ (2012) (Table 2). The cumulative AIDS incidence probability were 33.43 , $35.37,36.38,36.96$ and $37.04 \%$ in $1-5$ years of follow-up, respectively (Table 3).

\section{AIDS progression in patients treated with HAART}

The prevalence of AIDS in Zhejiang from 2008 to 2010 was $35.7 \%$, and it decreased to $27.9 \%$ between 2011 and 2012 (Table 2). To initially qualify for treatment with HAART (2008-2010), patients needed a CD4+ T-cell count of less than or equal to 200 cells $/ \mathrm{mm}^{3}$; however, the eligibility for HAART treatment was broadened to include patients with a CD4+ T-cell count of less than 350 cells $/ \mathrm{mm}^{3}$ (2011-2012) (Table 2). Figure 1 show
Table 1 Selected characteristics of patients with HIV infection in Zhejiang province

\begin{tabular}{|c|c|c|}
\hline Characteristic & Number (total $=9216$ ) & $\%$ \\
\hline \multicolumn{3}{|l|}{ Sex } \\
\hline Male & 6961 & 75.6 \\
\hline Female & 2242 & 24.4 \\
\hline \multicolumn{3}{|l|}{ Occupation } \\
\hline Farmer & 1788 & 19.4 \\
\hline Worker & 2365 & 25.7 \\
\hline Unemployed & 994 & 10.8 \\
\hline Commercial service & 1764 & 19.2 \\
\hline $\begin{array}{l}\text { Doctor, teacher, retired people, govern- } \\
\text { ment officials }\end{array}$ & 526 & 5.7 \\
\hline Others & 1766 & 19.2 \\
\hline \multicolumn{3}{|l|}{ Marriage } \\
\hline Unmarried & 3396 & 36.9 \\
\hline Married & 4166 & 45.3 \\
\hline Divorced or widowed & 1588 & 17.3 \\
\hline Unknown & 53 & 0.6 \\
\hline \multicolumn{3}{|l|}{ Ethnic group } \\
\hline Han & 8548 & 92.9 \\
\hline Other & 651 & 7.1 \\
\hline Unknown & 4 & 0.0 \\
\hline \multicolumn{3}{|l|}{ Education } \\
\hline Primary school or under & 2461 & 26.7 \\
\hline Junior high school & 3879 & 42.1 \\
\hline Senior high school & 1634 & 17.8 \\
\hline College or above & 1226 & 13.3 \\
\hline Unknown & 3 & 0.0 \\
\hline \multicolumn{3}{|l|}{ Age (years) } \\
\hline $0-24$ & 1964 & 21.3 \\
\hline $25-34$ & 3196 & 34.7 \\
\hline $35-44$ & 2215 & 24.1 \\
\hline $45-54$ & 993 & 10.8 \\
\hline 55 or above & 835 & 9.1 \\
\hline \multicolumn{3}{|l|}{ Census register } \\
\hline Zhejiang Province & 4837 & 52.6 \\
\hline Other Province & 4366 & 47.4 \\
\hline
\end{tabular}

that AIDS progression rates decreased in all CD4 level groups except the unknown one. The largest reduction in the rate of AIDS progression was observed in patients with a baseline CD4+ T-cell count of 200-350 cells $/ \mathrm{mm}^{3}(25.8 / 100$ py of the patients in $2008-2010$ and $17.7 / 100$ py of the patients in $2011-2012, \mathrm{P}<0.001$ ). Figure 2 indicates that the progression rates for all modes of transmission decreased after the eligibility criteria for HAART were broadened to include patients with a CD4+ T-cell count of less than 350 cells $/ \mathrm{mm}^{3}$. In particular, patients who were infected by HIV through homosexual transmission showed the most dramatic 
Table 2 AIDS progression rates by time period

\begin{tabular}{|c|c|c|c|c|c|c|c|}
\hline \multirow[t]{2}{*}{ Time period } & \multirow{2}{*}{$\begin{array}{l}\text { Person-years } \\
\text { of observation } \\
\text { (py) }\end{array}$} & \multirow{2}{*}{$\begin{array}{l}\text { Incidence } \\
\text { observed (n) }\end{array}$} & \multirow{2}{*}{$\begin{array}{l}\text { AIDS progression } \\
\text { rate (/100 py) }\end{array}$} & \multicolumn{2}{|l|}{ Male } & \multicolumn{2}{|l|}{ Female } \\
\hline & & & & AIDS, n (py) & $\begin{array}{l}\text { AIDS progression } \\
\text { rate (/100 py) }\end{array}$ & AIDS, n (py) & $\begin{array}{l}\text { AIDS progression } \\
\text { rate (/100 py) }\end{array}$ \\
\hline 2008 & 1093 & 370 & 33.9 & $243(714)$ & 34.0 & $127(379)$ & 33.6 \\
\hline 2009 & 1626 & 546 & 33.6 & 395 (1112) & 35.5 & $151(514)$ & 29.4 \\
\hline 2010 & 2296 & 874 & 38.1 & $676(1618)$ & 41.8 & $198(678)$ & 29.2 \\
\hline 2008-2010 & 5015 & 1790 & $35.7^{*}$ & $1314(3444)$ & $38.2^{*}$ & 476 (1571) & $30.3^{*}$ \\
\hline 2011 & 3163 & 969 & 30.6 & 726 (2317) & 31.3 & $243(846)$ & 28.7 \\
\hline 2012 & 4274 & 1109 & 25.9 & 869 (3232) & 26.9 & $240(1042)$ & 23.0 \\
\hline 2011-2012 & 7437 & 2078 & $27.9^{*}$ & $1595(5549)^{*}$ & $28.8^{*}$ & 483 (1888) & $25.6^{*}$ \\
\hline
\end{tabular}

* Pearson $\chi^{2}$ test, $P$ value for AIDS progression rates $2008-2010$ vs. 2011-2012 of whole group, male and female are $0.000,0.000,0.002$, respectively

\begin{tabular}{|c|c|c|c|}
\hline $\begin{array}{l}\text { Time to AIDS } \\
\text { onset (year) }\end{array}$ & AIDS (n) & $\begin{array}{l}\text { Incidence prob- } \\
\text { ability (\%) }\end{array}$ & $\begin{array}{l}\text { Cumulative incidence } \\
\text { probability (\%) }\end{array}$ \\
\hline $0-$ & 2763 & 33.43 & 33.43 \\
\hline $1-$ & 335 & 5.81 & 35.37 \\
\hline $2-$ & 151 & 2.84 & 36.38 \\
\hline $3-$ & 81 & 1.59 & 36.96 \\
\hline $4-$ & 12 & 0.24 & 37.04 \\
\hline Total & 3342 & - & - \\
\hline
\end{tabular}

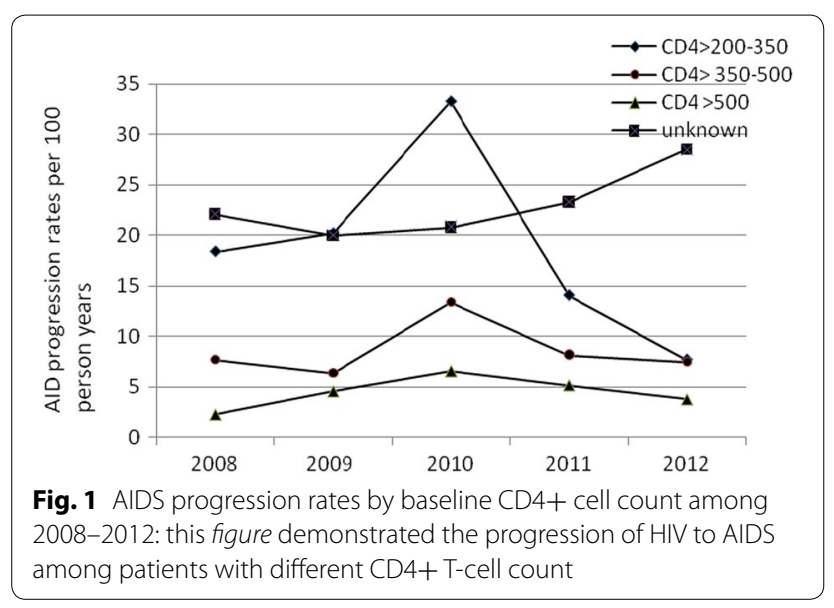

reduction in the rates of AIDS (36.2/100 py in 2008-2010 to $23.6 / 100$ py in $2011-2012, P<0.001)$.

\section{Changes over calendar time}

The demographic characteristics of patients changed over the course of this study, from 2008 to 2012. In 2012, patients with first positive HIV test had a higher median age (39.8 years) compared with that of the comparable group of patients in 2008 (37.9 years old) $(P<0.05)$; HIV

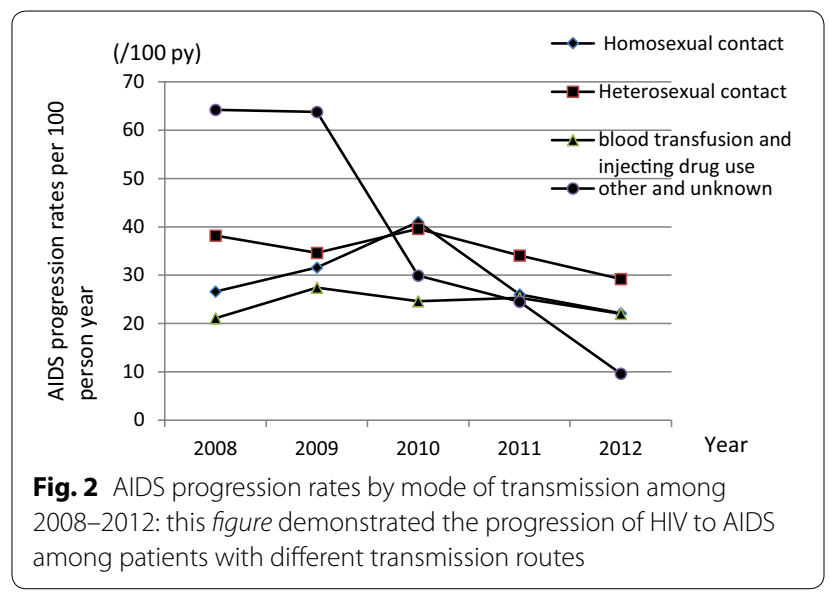

infection from homosexual transmission occurred more frequently in patients in $2012(36.4 \%)$ compared with in 2008 (18.8 \%) $(P<0.001)$; However, baseline CD4 T-cell count counts were similar in 2008 and 2012 (median: 319 and $328 \mathrm{cell} / \mu \mathrm{l}$, respectively; $P>0.05$ ); The rate of HAART treatment during the first year of diagnosed with HIV was significantly higher $(27.5 \%)$ in 2012 than in $2008(3.1 \%)(P<0.001)$.

\section{Risk factors involved in the progression of HIV to AIDS}

Patients in Group Two (3989 patients) were followed up for 12,452 py. As of December 31, 2012, it was known that 611 patients had progressed to AIDS. Cox proportional hazards regression was performed to determine the relative contribution of each factor (i.e., demographic characteristics, mobility, transmission routes, year of diagnosis, treatment with HAART and CD4+ T-cell count at baseline) to the progression of HIV of AIDS (Table 4). Cox regression analysis revealed that several factors, including age at diagnosis, transmission routes, census register, year of diagnosis, baseline CD4+ T-cell count and CD4+ T-cell count 
Table 4 Cox proportional hazards model of risk factors for development of AIDS

\begin{tabular}{|c|c|c|c|c|}
\hline Risk factor & $\begin{array}{l}\text { Unadjusted relative hazard } \\
H R(95 \% C l)\end{array}$ & $P$ & $\begin{array}{l}\text { Adjusted relative hazard } \\
H R(95 \% \mathrm{Cl})\end{array}$ & $P$ \\
\hline \multicolumn{5}{|l|}{ Sex } \\
\hline Male & 1 (reference) & & - & - \\
\hline Female & $0.996(0.827-1.200)$ & 0.966 & - & - \\
\hline \multicolumn{5}{|l|}{ Age (year) } \\
\hline $0 \sim$ & 1 (reference) & & 1 (reference) & \\
\hline $25 \sim$ & $1.176(0.949-1.457)$ & 0.139 & $1.221(0.982-1.518)$ & 0.072 \\
\hline $35 \sim$ & $1.310(1.031-1.666)$ & 0.027 & $1.364(1.065-1.746)$ & 0.014 \\
\hline $45 \sim$ & $1.556(1.167-2.075)$ & 0.003 & $1.692(1.247-2.297)$ & 0.001 \\
\hline $55 \sim$ & $1.950(1.412-2.694)$ & 0.000 & $1.915(1.357-2.703)$ & 0.000 \\
\hline \multicolumn{5}{|l|}{ Education } \\
\hline Primary school and under & 1 (reference) & & - & - \\
\hline Junior high school & $0.981(0.798-1.206)$ & 0.856 & - & - \\
\hline Senior high school & $0.943(0.739-1.205)$ & 0.641 & - & - \\
\hline College and above & $0.874(0.673-1.135)$ & 0.312 & - & - \\
\hline \multicolumn{5}{|l|}{ Marital status } \\
\hline Single & 1 (reference) & & - & - \\
\hline Married & $1.198(1.007-1.425)$ & 0.042 & - & - \\
\hline Divorced or widowed & $1.094(0.863-1.386)$ & 0.457 & - & - \\
\hline Unknown & $1.313(0.486-3.526)$ & 0.590 & - & - \\
\hline \multicolumn{5}{|l|}{ Mode of transmission } \\
\hline Homosexual contact & 1 (reference) & & 1 (reference) & \\
\hline Heterosexual contact & $1.019(0.862-1.205)$ & 0.824 & $0.695(0.571-0.844)$ & 0.000 \\
\hline Blood & $0.789(0.514-1.212)$ & 0.279 & $0.524(0.336-0.816)$ & 0.004 \\
\hline Other and unknown & $0.951(0.470-1.927)$ & 0.890 & $0.689(0.336-1.415)$ & 0.311 \\
\hline \multicolumn{5}{|l|}{ Testing mode } \\
\hline VCT consultant & 1 (reference) & & & - \\
\hline Health checkup & $1.027(0.807-1.306)$ & 0.831 & - & - \\
\hline Seeing doctor for other disease & $1.261(1.006-1.579)$ & 0.044 & - & - \\
\hline Spouse and children of patient, blood donors & $1.380(1.007-1.891)$ & 0.045 & - & - \\
\hline Others & $1.112(0.720-1.718)$ & 0.633 & - & - \\
\hline \multicolumn{5}{|l|}{ Census register } \\
\hline Zhejiang Province & 1 (reference) & & 1 (reference) & \\
\hline Other Province & $0.765(0.651-0.898)$ & 0.001 & $0.670(0.562-0.799)$ & 0.000 \\
\hline \multicolumn{5}{|l|}{ Mobility } \\
\hline Between Provinces & 1 (reference) & & - & - \\
\hline Between Cites & $0.905(0.636-1.287)$ & 0.579 & - & - \\
\hline Between County & $0.977(0.777-1.228)$ & 0.840 & - & - \\
\hline Immobility & $0.970(0.795-1.182)$ & 0.761 & - & - \\
\hline \multicolumn{5}{|l|}{ Reported time (year) } \\
\hline $2008-2010$ & 1 (reference) & & 1 (reference) & \\
\hline $2011-2012$ & $0.346(0.274-0.437)$ & 0.000 & $0.382(0.302-0.483)$ & 0.000 \\
\hline \multicolumn{5}{|l|}{ Baseline CD4+ T-cell count } \\
\hline $200-350$ & 1 (reference) & 0.000 & 1 (reference) & \\
\hline $350-500$ & $0.464(0.388-0.556)$ & 0.000 & $0.380(0.316-0.458)$ & 0.000 \\
\hline$>500$ & $0.262(0.206-0.332)$ & 0.000 & $0.187(0.147-0.239)$ & 0.000 \\
\hline \multicolumn{5}{|l|}{ CD4+ T-cell count of initial HAART } \\
\hline No HAART & 1 (reference) & & 1 (reference) & \\
\hline$\leq 200$ & $2.166(1.273-3.685)$ & 0.004 & $1.165(0.679-1.999)$ & 0.580 \\
\hline
\end{tabular}


Table 4 continued

\begin{tabular}{llll}
\hline Risk factor & $\begin{array}{l}\text { Unadjusted relative hazard } \\
\boldsymbol{H R}(\mathbf{9 5} \% \mathbf{C l})\end{array}$ & $\boldsymbol{P}$ & $\begin{array}{l}\text { Adjusted relative hazard } \\
\boldsymbol{H}(\mathbf{9 5} \% \mathrm{Cl})\end{array}$ \\
\hline $200-350$ & $0.402(0.320-0.504)$ & 0.000 & $0.225(0.178-0.285)$ \\
$>350$ & $0.295(0.110-0.789)$ & 0.015 & $0.168(0.063-0.451)$ \\
\hline
\end{tabular}

VCT voluntary counselling test

of initial HAART played significant influence roles in the progression of HIV to AIDS. HIV patients older than 55 years showed a higher risk of progressing to AIDS than patients who were younger than 25 years old $(H R=1.915,95 \%$ CI: 1.357-2.703, $P<0.001)$. The rate of AIDS progression was significantly higher among those infected by homosexual transmission than among patients infected by heterosexuals transmission $(H R=0.695,95 \% \mathrm{CI}: 0.571-0.844, P<0.05)$ or by blood borne transmission $(H R=0.524,95 \%$ CI: $0.336-$ $0.816, P<0.05)$. Patients diagnosed with HIV between 2011 and 2012 were at a lower risk of acquiring AIDS than were those patients diagnosed between 2008 and $2010(H R=0.382,95 \%$ CI: 0.302-0.483, $P<0.001)$. Our results also indicate that a higher CD4+ T-cell count was associated with a lower rate of AIDS progression $(H R=0.380,0.187, P<0.001)$. Patients with a CD4+ T-cell count of $200-350$ cells $/ \mathrm{mm}^{3}$ or greater than 350 cells $/ \mathrm{mm}^{3}$ were less likely to develop AIDS following HIV diagnosis than were those patients without HAART treatment $(H R=0.225,0.168, P<0.001)$ (Table 4).

\section{Discussion}

The rate at which HIV progressed to AIDS decreased from $33.9 \%$ in 2008 to $25.9 \%$ in 2012 . These rates were greater than those observed in developed countries, such as British Columbia (7 \% in 2013), Brazil (6.2 \% between 2000 and 2008), but they were similar to the rates in Africa and Asia countries [12-16]. In this study, AIDS was diagnosed within 1 year of HIV diagnosis, which is similar to the diagnostic process in developed countries. The rates at which patients diagnosed with HIV progressed to AIDS within 12 months in developed countries were as follows: Australia: $65.0 \%$, Canada: $64.0 \%$ and France: $64.8 \%$ [17]. Our study found late diagnosis of HIV in Zhejiang and other Chinese provinces, which probably affects the survival of patients.

Several studies in developed countries have demonstrated that non-HAART treatment, hepatitis B coinfection, tuberculosis coinfection, being older than 50 years of age, having black or brown skin, intravenous drug abuse, lack of schooling as well as a baseline CD4+ T-cell count lower than 500 cells $/ \mathrm{mm}^{3}$ were predictors of higher rate of AIDS progression [18-20].
The results from our study suggest that increasing the CD4+ T-cell count necessary to begin HAART treatment is an effective way to delay AIDS progression among PLHIV. The overall AIDS progression rate underwent a steady reduction after 2010 (from 38.1 to $25.9 \%$ ) as the treatment was available to patients with a CD4+ T-cell count of 350 cells $/ \mathrm{mm}^{3}$ [21]. Our analysis also indicated that patients with a CD4 $+\mathrm{T}$-cell count greater than 200-350 cells $/ \mathrm{mm}^{3}$ benefit the most from early HAART treatment. The progression rate for patients with unknown CD4+ T-cell counts increased over time, with $33.5 \%$ of these patients being diagnosed at the time of death. We hypothesize that these phenomena relate to the fact that these specific individuals did not seek care in time. Furthermore, most of these patients were migrants, had lower lever of education, and older. HAART plays an important role in delaying the progression of HIV to AIDS because it can reduce the HIV-RNA concentration and restoring the immune system [22-24]. In recent years, increasing number of researches encouraged early treatment with CD4+ T-cell count less than 500 cells/ $\mathrm{mm}^{3}$ or more [25-27]. Although the beneficial effects of HAART have been already observed in patients with a CD4+ T-cell count greater than 200 cells $/ \mathrm{mm}^{3}$, or greater than or equal to 350 cells $/ \mathrm{mm}^{3}$, developing counties, including Asia and Africa, need to understand other important factors [e.g. economic factors, side effects or serious non AIDS events (ANAEs) like cancer and cardiovascular disease].

Several factors, including mode of transmission, region, age and CD4+ T-cell count at baseline were related to the rate of AIDS progression in HIV-positive patients. A study performed by Hongjing Yan found a higher rate of disease progression from HIV to AIDS among homosexuals compared with among heterosexuals, intravenous drug users (IDUs) or blood donors [8]. Similar results were observed in this study; however, the proportion of late diagnosis in male who have sex with male (MSM) patients was $19.1 \%$, which was lower than that of heterosexuals (30.9\%) and others (29.7\%) in Zhejiang (data not published). The high rate of AIDS progression among homosexual patients might be a result of other important factors including stigma, psychological characteristics, genetic or molecular characteristics, as well as coinfection with other disease, such as hepatitis; or tuberculosis 
[28]. Although this information was not collected in our particular patient database, further investigations are warranted. In Zhejiang, the central regions have the highest rate of AIDS development, which might be related to the fact that these regions contain the highest proportions of homosexuals. A study in Hangzhou conducted between 2006 and 2008 indicated that the infection rates of homosexuals from pubs, bathrooms and clubhouses were $3.5,12.8$ and $2.8 \%$, respectively, all of which were higher than those observed in any other cities in Zhejiang $[29,30]$. The results of our study also suggest that age and baseline CD4+ T-cell count were critical factors that determine the rate of progression of HIV to AIDS. Patients who have lower baseline CD4+ T-cell count and were of an older age tended to have a higher \%consistent with previously published works [31].

This retrospective cohort study of patients from Zhejiang, provides information on the rate and contributors to the progression of HIV to AIDS. Our observations highlight the impact of late HIV testing and delayed diagnosis of HIV/AIDS in Zhejiang. Previous studies have suggested that an undamaged immune system predicts delayed progression to AIDS [32] and late diagnosis leads to exhaustion of the immune system. Therefore, the use of additional strategies, such as VCT and provider-initiated HIV testing and counseling (PITC), for HIV screening is necessary to delay the progression of HIV to AIDS.

\section{Limitations}

This has a few limitations. As the cohort was not strictly designed, inaccurate follow-up was inevitable. First, the amount of time between HIV diagnosis to AIDS diagnosis might have been exaggerated or underestimated. Second, CD4+ T-cell count, which is an important diagnostic tool for AIDS, was not available for all patients. A large number subjects are excluded in group two for their AIDS status as diagnosis and without CD4+ T-cell count in first 3 month following diagnosis were excluded for confounding variables, which may have introduced selection bias. Although we recommend early HAART treatment, data on side effect or additional information regarding earlier treatment have not been reported. The role of early HAART treatment in patient health will need to be assessed in the future.

\section{Conclusions}

In conclusion, HIV progression to AIDS was affected by the patient's age at diagnosis, transmission routes and baseline CD4+ T-cell counts. Early HAART treatment in patients with a higher CD4+ T-cell count significantly delayed progression to AIDS in these patients. Thus effective interventions, such as PITC or VCT, should be utilized to target those at high risk. Our results support use of early HAART treatment, an approach that is already recommended by the current WHO treatment guidelines for HIV infection.

\section{Authors' contributions}

LC carried out study design as well as data collection, data analysis, and write manuscript. XHP designed the study, reviewed the manuscript and approved the final version. RJZ and PCY revised the manuscript. JMJ and NW reviewed the manuscript. JZY, YX, JLZ, JJ, LH helped to collect and manage data. All authors read and approved the final manuscript.

\section{Author details \\ ${ }^{1}$ Zhejiang Provincial Center for Diseases Control and Prevention, Hangzhou, China. ${ }^{2}$ National Center for AIDS/STD Control and Prevention, China CDC, Bei- jing, China. ${ }^{3}$ Department of Surgery, Faculty of Medicine, The Chinese Univer- sity of Hong Kong, Shatin, Hong Kong. ${ }^{4}$ Department of HIV/AIDS Prevention and Control, Zhejiang Provincial Center for Diseases Control and Prevention, 3399 Binsheng Road, Hangzhou, Zhejiang, People's Republic of China.}

\section{Acknowledgements}

The authors thank the staff of local Health Bureaus and local CDCs in Zhejiang province for their assistance in the fieldwork.

\section{Grant support}

Our funding was provided by The National Science and Technology Pillar Program (Grant No. 2012ZX10001001).

\section{Sources of support}

Key Projects in the National Science and Technology Pillar Program during the Twelfth five-year plan period (Grant No. 2012ZX10001001).

\section{Compliance with ethical guidelines}

\section{Competing interests}

The authors declare that they have no competing interests.

Received: 6 January 2015 Accepted: 16 September 2015 Published online: 25 September 2015

\section{References}

1. Barré-Sinoussi F, Chermann JC, Rey F, et al. Isolation of a T-lymphotropic retrovirus from a patient at risk for AIDS. Science. 1983;220:868-71.

2. UNAIDS epidemic update 2007. http://www.who.int/hiv/pub/epidemiology/epiupdate2007/en/. Accessed 10 May 2013.

3. Wang L, Wang L, Ding ZW, et al. HIV prevalence among populations at risk, using sentinel surveillance data from 1995 to 2009 in China. Chin J Epidemiol. 2011;32:20-4.

4. BBC News. Aids take deathly toll in China. February 18, 2009. http://news. bbc.co.uk/2/hi/asia-pacific/7896133.stm/. Accessed 2 May 2012.

5. Shen J, Yu D. Governmental policies on HIV infection in China. Cell Res. 2005;15:903-7.

6. Wang ZY, Zheng YF, Liu L, et al. High prevalence of HIV-associated neurocognitive disorder in HIV-infected patients with a baseline CD4 count $\leq 350$ cells/ $\mathrm{LL}$ in Shanghai, China. Biosci Trends. 2013;7:284-9.

7. Wu JR, Wang B, Zhou LJ, et al. Mycoplasmas infection in male HIV/AIDS patients in Jiangsu, China. Microb Pathog. 2013;63:54-8.

8. Yan HJ, Yang HT, Li JJ, et al. Emerging disparity in HIV/AIDS disease progression and mortality for men who have sex with men, Jiangsu Province, China. AIDS Behav. 2014;51:5-10.

9. Yoichi C, Kavita V. Adverse psychosocial factors predict poorer prognosis in HIV disease: a meta-analytic review of prospective investigations. Brain Behav Immun. 2009;23:434-45.

10. Steele KT, Steenhoff AP, Newcomb CW, et al. Early mortality and AIDS progression despite high initial antiretroviral therapy adherence and virologic suppression in Botswana. PLoS One. 2011;6(6):e20010.

11. World Health Organization (WHO). HIV/AIDS Programme. WHO case definitions of HIV for surveillance and revised clinical staging and immunological classification of HIV-related disease in adults and children. 
2006. http://www.who.int/hiv/pub/guidelines/hivstaging/en/. Accessed 13 May 2014

12. Nicola L, Katie P, Rebecca C, et al. AIDS survival and progression in black Africans living in south London, 1986-1994. Genitourin Med. 1996;72:12-6.

13. Lima VD, Lourenço L, Yip B, et al. Trends in AIDS incidence and AIDSrelated mortality in British Columbia between 1981 and 2013. Lancet HIV. 2015;2(3):e92-7.

14. Luz PM, Bruyand M, Ribeiro S. AIDS and non-AIDS severe morbidity associated with hospitalizations among HIV-infected patients in two regions with universal access to care and antiretroviral therapy, France and Brazil, 2000-2008: hospital-based cohort studies. BMC Infect Dis. 2014;21(14):278

15. Gabillard D, Lewden C, Ndoye I. Mortality, AIDS-morbidity, and loss to follow-up by current CD4 cell count among HIV-1-infected adults receiving antiretroviral therapy in Africa and Asia: data from the ANRS 12222 collaboration. J Acquir Immune Defic Syndr. 2013;62(5):555-61.

16. Jiang HB, Xie NH, Cao BB. Determinants of progression to AIDS and death following HIV diagnosis: a retrospective cohort study in Wuhan, China. PLoS One. 2013;8(12):e83078.

17. Hall HI, Halverson J, Wilson DP. Late diagnosis and entry to care after diagnosis of human immunodeficiency virus infection: a country comparison. PLoS One. 2013;8(11):e77763.

18. Tancredi MV, Waldman EA. Predictors of progression to AIDS after HIV infection diagnosis in the pre- and post-HAART eras in a BrazilianAIDSfree cohort. Trans R Soc Trop Med Hyg. 2014;108(7):408-14.

19. Edelman EJ, Cheng DM, Krupitsky EM. Heroin use and HIV disease progression: results from a Pilot Study of a Russian Cohort. AIDS Behav. 2015;19(6):1089-97.

20. Kawado M, Hashimoto S, Yamaguchi T. Difference of progression to AIDS according to CD4 cell count, plasma HIV RNA level and the use of antiretroviral therapy among HIV patients infected through blood products in Japan. J Epidemiol. 2006;16(3):101-6.

21. WHO. Rapid advice: antiretroviral therapy for HIV infection in adults and adolescents. http://www.who.int/hiv/pub/arv/rapid_advice_art.pdf. Accessed 15 May 2013.

22. Li $X, X u Y$, Nie S, et al. The effect evaluation of highly active antiretroviral therapy to patients with AIDS in Hubei province of China. J Huazhong Univ Sci Technol Med Sci. 2009;29:580-4.
23. Wong KH, Chan KCW, Lee SS, et al. Delayed progression to death and to AIDS in a Hong Kong cohort of patients with advanced HIV type 1 disease during the era of highly active antiretroviral therapy. Clin Infect Dis. 2004;39:853-60

24. Pezzotti P, Dorrucci M, Donisi A, et al. Survival, progression to AIDS and immunosuppression in HIV-positive individuals before and after the introduction of the highly active antiretroviral therapy (HAART). Epidemiol Prev. 2003;27:348-55.

25. Drechsler $\mathrm{H}$, Zhang S, Holodniy M, et al. CD4 counts and mortality in virologically suppressed US veterans. J Int Assoc Provid AIDS Care. 2014;13(2):120-6.

26. Cagigi A, Rinaldi S, Cotugno N, et al. Early highly-active antiretroviral therapy enhances B-cell longevity: a 5 year follow-up. Pediatr Infect Dis J. 2014;33(5):e126-31.

27. Mills FP, Ford N, Nachega JB, et al. Earlier initialization of highly active antiretroviral therapy is associated with long-term survival and is costeffective: findings from a deterministic model of a 10-year Ugandan cohort. J Acquir Immune Defic Syndr. 2012;61 (3):364-9.

28. Lim HJ, Okwera A, Mayanja-Kizza H. Effect of tuberculosis preventive therapy on HIV disease progression and survival in HIV-infected adults. HIV Clin Trials. 2006;7(4):172-83.

29. Shao B, Li Y, Yu L, et al. The HIV/AIDS epidemic characteristics in a northeast province of China - men who have sex with men have made a tremendous contribution to the growth of the HIV epidemic. J Infect. 2014;68(3):273-80.

30. Wraivg LH, Xu YY, Weivg J, et al. Cross-sectional investigation on HIV prevalence and HIV related risk behavior among men who have sex with men in Taizhou, Zhejiang. Dis Surveill. 2013;1:362-5.

31. Symeon M, Olga T, Lemonia S, et al. Older HIV-infected patients — an underestimated population in northern Greece: epidemiology, risk of disease progression and death. Int J Infect Dis. 2013;17:e883-91.

32. Maloy KJ, Burkhart C, Junt TM, et al. CD4pT cell subsets during virus infection. Protective capacity depends on effector cytokine secretion and on migratory capability. J Exp Med. 2000;191:2159-70.

\section{Submit your next manuscript to BioMed Central and take full advantage of:}

- Convenient online submission

- Thorough peer review

- No space constraints or color figure charges

- Immediate publication on acceptance

- Inclusion in PubMed, CAS, Scopus and Google Scholar

- Research which is freely available for redistribution

Submit your manuscript at

www.biomedcentral.com/submit

C BioMed Central 